Scientia Agricola

http://dx.doi.org/10.1590/0103-9016-2013-0301

\title{
Lettuce genotype resistance to "soft rot" caused by Pectobacterium carotovorum
}

\section{subsp. carotovorum}

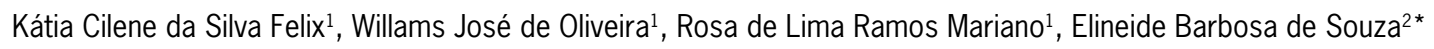

${ }^{1}$ Federal Rural University of Pernambuco - Dept. of Agronomy.

${ }^{2}$ Federal Rural University of Pernambuco - Dept. of Biology, Av. Dom Manoel de Medeiros, s/n, Dois Irmãos - 52171-900

- Recife, PE - Brazil.

*Corresponding author <elineidebs@yahoo.com.br>

Edited by: Emerson Medeiros Del Ponte

Received September 11, 2013

Accepted January 20, 2014
ABSTRACT: Soft rot, caused by Pectobacterium carotovorum subsp. carotovorum (Pcc), is the main bacterial disease affecting lettuce (Lactuca sativa L.) crops in Brazil and leads to significant yield losses. This study aimed to assess the reaction of lettuce genotypes to soft rot induced by a virulent isolate and the stability of the resistance to three isolates varying in virulence. Using a descriptive ordinal scale ranging from 1 to 9 a classification system was defined: class $1=$ resistant (R): severity $(\mathrm{Sev})<1.5$; class $2=$ moderately resistant (MR): $1.5 \leq \operatorname{Sev}<2.5$; class 3 = susceptible (S): $2.5 \leq \operatorname{Sev}<3.5$; class 4 = highly susceptible (HS): Sev $\geq 3.5$ ). Of the 41 tested genotypes, 14 were classified as MR and 27 as S when inoculated with a Pcc isolate of intermediate virulence. Eleven of these genotypes (four $S$ and seven MR) were selected to test their resistance stability against three other isolates with an increasing degree of virulence (Pcc$36<$ Pcc-A1.1 < Pcc-23). Out of the 11 genotypes eight retained the original classification and three moved from $S$ to MR resistant class when challenged with the least virulent isolate. Vitória de Santo Antão was the only genotype classified as MR for all tested isolates and is a promising candidate for durable soft rot resistance breeding.

Keywords: Lactuca sativa, bacterial, disease control

\section{Introduction}

Lettuce (Lactuca sativa L.) is one of the most widely consumed leafy vegetables (in the form of salad) and is cultivated all over Brazil during different periods throughout the year. Currently, it is among the six most economically important vegetables and is the eighth largest in terms of volume produced (Sala and Costa, 2012).

Soft rot caused by Pectobacterium carotovorum subsp. carotovorum (Jones) Hauben et al. is considered the main bacterial disease of several economically important crops not only in Brazil but also worldwide (Charkowski, 2006; Zhang et al., 2012), including lettuce (Cariddi and Sanzani, 2013). In the state of Pernambuco, in the northeast of Brazil, lettuce production is concentrated in the municipality of Vitória de Santo Antão, where it is usually planted with successive crops throughout the year, and soft rot can cause extensive losses, mainly under high temperature and humidity conditions.

Disease control is hampered primarily by the broad range of host plants and the ability of the bacteria to survive on crop residues (Jung et al., 2008; Koh et al., 2013; Ren et al., 2001a). The use of resistant cultivars is considered the most cost-effective and technically feasible control method as compared with the use of pesticides that, in some cases, may lead to pesticide resistance in the pathogenic populations and accumulate in the consumable product as harmful residues.

Earlier studies have confirmed the efficacy of host resistance to control soft rot in potato (Solanum tuberosum L.) (Vitale et al., 2004), Chinese cabbage (Brassica pekinensis L.) (Ren et al., 2001b), arracacha (Arracacia xanthorrhiza Bancroft) (Henz et al., 2005) and Zantedeschia spp. crops (Snijder and Tuyl, 2002). However, information on the soft rot resistance of lettuce genotypes is lacking. Because soft rot may be a strong limiting factor for lettuce production in some areas, the present study aimed to identify sources of resistance to soft rot caused by $P$. carotovorum subsp. carotovorum in a collection of lettuce genotypes and to assess the resistance stability of selected genotypes to isolates varying in virulence.

\section{Materials and Methods}

\section{Origin and pathogenicity of the isolates}

The $P$. carotovorum subsp. carotovorum isolates used in this study were obtained from the Culture Collection of the Laboratory of Plant Bacteriology, Federal Rural University of Pernambuco, and were isolated from Chinese cabbage and lettuce plants exhibiting typical soft rot symptoms.

Twenty strains were reactivated from cultures preserved in water by culturing in casamino-acid-peptoneglucose (CPG) medium (1 g casein hydrolysate, $10 \mathrm{~g}$ peptone, $10 \mathrm{~g}$ glucose and $18 \mathrm{~g}$ agar in $1 \mathrm{~L}$ distilled water) for $48 \mathrm{~h}$ at $28{ }^{\circ} \mathrm{C}$. Pure colonies were transferred to test tubes containing the same medium. After $48 \mathrm{~h}$, the pathogenicity of each isolate was tested on green bell pepper fruits, as described by Hyman et al. (2002). The peppers were placed in a moist chamber and incubated at $28{ }^{\circ} \mathrm{C}$ for 24 $48 \mathrm{~h}$, after which virulence of the isolates was evaluated by measuring the sizes of the lesions.

Four isolates that exhibited various degrees of virulence were selected. In ascending order of virulence: Pcc36 (Chinese cabbage), Pcc-C (Chinese cabbage), Pcc-A1.1 (green leaf lettuce) and Pcc-23 (loose-leaf lettuce). These isolates were cultured on CPG medium for $48 \mathrm{~h}$ at $28{ }^{\circ} \mathrm{C}$. Sterile distilled water was then added to the Petri dishes 
containing the bacteria, and the concentration of the bacterial suspension was adjusted using a spectrophotometer at $570 \mathrm{~nm}$, where $\mathrm{A}_{570}=0.36$ is equal to $1 \times 10^{9} \mathrm{CFU} \mathrm{mL} \mathrm{m}^{-1}$.

\section{Selection of lettuce genotypes resistant to soft rot}

We evaluated 40 commercial lettuce cultivars and one additional line (Raider Plus). These genotypes belong to five lettuce types: crisphead, green leaf, looseleaf, mimosa, and romaine (Table 1). Among the tested genotypes, Tainá was used as a standard for soft rot susceptibility (Silva et al., 2007). These genotypes were tested for their resistance to the disease induced by the isolate Pcc-C that had an intermediate degree of virulence among the four isolates.

The lettuce genotypes were sown in 200-cell expanded polystyrene trays containing a $1: 1(\mathrm{v} / \mathrm{v})$ mixture of a commercial substrate and coconut (Cocos nucifera L.) coir. Twenty days after sowing, the seedlings were transplanted to $5 \mathrm{~L}$ pots containing a $1: 2(\mathrm{v} / \mathrm{v})$ mixture of humus and soil.

Thirty-five day old plants were inoculated at the base of the petiole of the second and third true leaves using the pinprick method adapted from Ren et al. (2001a), in which the plant tissue is penetrated with the insertion of an entomological pin to a depth of $1 \mathrm{~mm}$. Subsequently, $50 \mu \mathrm{l}$ of bacterial suspension were inoculated into the wound using a micropipette. Following inoculation, the plants were placed for $12 \mathrm{~h}$ in a moist chamber, inside a greenhouse. The experimental design was completely randomized with five replicates. Each replicate consisted of one pot with four plants, and the experiment was repeated twice. The mean temperature and relative air humidity were $27.5^{\circ} \mathrm{C}$ and $70 \%$ during the first experiment and $26.27{ }^{\circ} \mathrm{C}$ and $76 \%$ during the second.

Plants were evaluated at 12-h intervals for up to 96 $\mathrm{h}$, and disease severity was assessed using a descriptive ordinal scale ranging from 1 to 9 (Ren et al., 2001a), where $1=$ no lesions at the inoculation site, $2=$ lesions smaller than $5 \mathrm{~mm}, 3=$ lesions between 5 and $10 \mathrm{~mm}, 4=$ lesions larger than $10 \mathrm{~mm}$ but not reaching the leaves, $5=$ lesions reaching the leaf blade and main stem, $6=$ infection reaching the stem but not the non-inoculated leaves, $7=$ infection reaching non-inoculated stems and leaves, $8=$ entire plant near death and $9=$ dead plant. Based on the mean values of 20 plants (four plants per pot and five replicates), the lettuce genotypes were grouped into classes representing their reaction (average score) to the disease using the following classification system: class $1=$ sistant (MR): $1.5 \leq \mathrm{Sev}<2.5$; class $3=$ susceptible $(\mathrm{S}): 2.5$ $\leq$ Sev $<3.5$; class 4 = highly susceptible (HS): Sev $\geq 3.5$ ).

\section{Soft rot resistance stability}

For this experiment, 11 lettuce genotypes were randomly selected based on their reaction to soft rot (four S and seven MR) as determined in the selection experiment, and including genotypes of the four lettuce types (loose-leaf, mimosa, crisphead and green leaf). resistant $(\mathrm{R})$ : severity $(\mathrm{Sev})<1.5$; class $2=$ moderately re-

These genotypes were inoculated with the other three Pcc isolates with increasing degree of virulence (Pcc$36<$ Pcc-A1.1 < Pcc-23). The growth, inoculation and evaluation of the lettuce seedlings were the same as in the selection experiment. The experimental design was completely randomized in a factorial arrangement of 11

Table 1 - Soft rot mean severity score and the corresponding resistance class of lettuce genotypes inoculated with Pectobacterium carotovorum subsp. carotovorum isolate of intermediate degree of virulence under greenhouse conditions.

\begin{tabular}{|c|c|c|c|}
\hline Genotype & $\begin{array}{l}\text { Mean severity } \\
\text { score }^{1}\end{array}$ & $\begin{array}{l}\text { Resistance } \\
\text { class }^{2}\end{array}$ & Type \\
\hline Vitória de Santo Antão & $2.0^{3} \mathrm{C}$ & MR & Loose-leaf \\
\hline Regina 255 & $2.0 \mathrm{c}$ & MR & Loose-leaf \\
\hline Lívia & $2.1 \mathrm{c}$ & MR & Loose-leaf \\
\hline Elisa & $2.1 \mathrm{c}$ & MR & Loose-leaf \\
\hline Livínia & $2.2 \mathrm{c}$ & MR & Mimosa \\
\hline Roxa 9 & $2.2 \mathrm{c}$ & MR & Green leaf \\
\hline Mimosa Salad Bowl Red & $2.2 \mathrm{c}$ & MR & Mimosa \\
\hline Red Salad Bowl & $2.2 \mathrm{c}$ & MR & Green leaf \\
\hline Imperial & $2.3 c$ & MR & Romaine \\
\hline Greek Lettuce & $2.3 c$ & MR & Mimosa \\
\hline Salad Bowl & $2.3 c$ & MR & Mimosa \\
\hline Red Salad Bowl Ultra Rosso & $2.4 \mathrm{~b}$ & MR & Mimosa \\
\hline Saia Veia & $2.4 \mathrm{~b}$ & MR & Loose-leaf \\
\hline Elba & $2.5 \mathrm{~b}$ & MR & Green leaf \\
\hline CNPH $54^{3}$ & $2.5 \mathrm{~b}$ & MR & Crisphead \\
\hline Vanda & $2.5 \mathrm{~b}$ & MR & Green leaf \\
\hline Olinda & $2.5 \mathrm{~b}$ & MR & Green leaf \\
\hline Simpson & $2.5 \mathrm{~b}$ & MR & Green leaf \\
\hline TPC 12047 & $2.5 \mathrm{~b}$ & MR & Mimosa \\
\hline Tainá & $2.6 \mathrm{~b}$ & $S$ & Crisphead \\
\hline Mônica & $2.6 \mathrm{~b}$ & S & Green leaf \\
\hline Grandes Lagos & $2.6 \mathrm{~b}$ & S & Crisphead \\
\hline Verônica & $2.6 \mathrm{~b}$ & S & Green leaf \\
\hline Mimosa Oak Leaf Green Pixie & $2.6 \mathrm{~b}$ & S & Mimosa \\
\hline Mimosa Salad Bowl & $2.7 \mathrm{~b}$ & S & Mimosa \\
\hline Solavis & $2.7 b$ & S & Green leaf \\
\hline Vanessa & $2.7 \mathrm{~b}$ & S & Green leaf \\
\hline Lucy Brown & $2.7 b$ & $S$ & Crisphead \\
\hline $18 \mathrm{BII}$ & $2.7 \mathrm{~b}$ & S & Mimosa \\
\hline Amélia & $2.7 \mathrm{~b}$ & $S$ & Crisphead \\
\hline Amanda & $2.7 \mathrm{~b}$ & S & Green leaf \\
\hline Scarlet & $2.8 \mathrm{~b}$ & $S$ & Green leaf \\
\hline Lettuce Red (1) & $2.8 \mathrm{~b}$ & S & Loose-leaf \\
\hline Raider Plus & $2.8 \mathrm{~b}$ & S & Crisphead \\
\hline Rafaela & $2.8 \mathrm{~b}$ & S & Crisphead \\
\hline Kaiser & $2.9 \mathrm{~b}$ & $S$ & Crisphead \\
\hline Lettuce Red (2) & $2.9 \mathrm{~b}$ & S & Green leaf \\
\hline Angelina & $2.9 \mathrm{~b}$ & S & Crisphead \\
\hline Cubana & $2.9 \mathrm{~b}$ & S & Green leaf \\
\hline Veneza Red & $3.0 \mathrm{~b}$ & S & Green leaf \\
\hline Red Hortec & $3.0 \mathrm{~b}$ & $S$ & Loose-leaf \\
\hline CV (\%) & 18.62 & & \\
\hline
\end{tabular}


genotypes $\times 3$ pathogen isolates. Five replicates were used and each consisted of one pot with four plants and the experiment was conducted twice. The mean temperature and relative air humidity were $29.37{ }^{\circ} \mathrm{C}$ and $72 \%$ during the first experiment and $28.63{ }^{\circ} \mathrm{C}$ and $70 \%$ during the second experiment.

\section{Statistical analysis}

The rank-transformed data of the first experiment were subjected to analysis of variance (ANOVA) and means were compared by the Scott-Knott test $(p<0.05)$. The relationship between the types of lettuce and resistance to soft rot was analyzed by the Kruskal-Wallis test $(p<0.05)$. In the second experiment the rank-transformed data were subjected to ANOVA and means were compared by the Least Significant Difference (LSD) test $(p<0.05)$. In both experiments ( 1 and 2$)$ the results of the two replicates were not different $(p<0.05)$, and the data were analyzed together.

\section{Results}

\section{Classification for soft rot resistance}

The collection of lettuce genotypes reacted differently to soft rot but formed only two classes (MR or S) according to the classification system (Table 1). Of the 41 tested genotypes, 19 were classified as MR (mean scores from 2.0 to 2.5 ) and 22 genotypes, including the standard for susceptibility, Tainá, were classified as S (mean scores from 2.6 to 3.0) (Table 1). None of the 41 genotypes was $R$ or HS or exhibited immune reaction (no disease).

Genotypes belonging to lettuce types crisphead, green leaf, loose-leaf and mimosa were found in both the MR and S classes. However, most genotypes of green leaf $(60 \%)$ and crisphead (88\%) types were in the S class while most genotypes of loose-leaf $(71 \%)$ and mimosa
$(67 \%)$ were in the MR class (Table 1). Comparing the lettuce types (Kruskall-Wallis, $p<0.05$ ), green leaf type showed mean severity score higher than mimosa and loose-leaf types but not from crisphead. The types looseleaf and mimosa presented the lowest scores of severity (data not presented).

\section{Stability of the soft rot resistance}

In the resistance-stability assay, when the least virulent isolate (Pcc-36) was used, no differences were observed $(p<0.05)$ among the 11 selected lettuce genotypes, which were previously grouped as moderately resistant (mean scores from 2.0 to 2.3) (Table 2). Seven genotypes (Greek Lettuce, Lívia, Livínia, Mimosa Salad Bowl Red, Saia Veia, Salad Bowl, and Vitória de Santo Antão) remained in the MR class as determined in the first experiment (Table 1). However, four genotypes that were previously classified as S (Veneza Red, Red Hortec, Lettuce Red (1) and Lucy Brown) reacted as MR to this least virulent isolate (Pcc-36). When inoculated with the isolate of intermediate virulence (Pcc-A1.1), five genotypes remained MR (mean scores from 2.1 to 2.4). The six remaining genotypes were reclassified as $\mathrm{S}$, with averages ranging from 2.5 to 3.0 (Table 2).

When the most virulent isolate (Pcc-23) was used, an additional resistant class, HS, was determined for Lucy Brown genotype (Table 2). Six MR genotypes were reclassified as S. Only one genotype, Vitória de Santo Antão, remained in the MR class when inoculated with the four $P$. carotovorum subsp. carotovorum isolates (Table 1 and 2), thus exhibiting stability for soft rot resistance.

\section{Discussion}

The MR class included $46 \%$ of the initial set of 41 genotypes and, among those, there were members of

Table 2 - Stability of host resistance, based on mean severity score to define a resistance class, to soft rot resistance for lettuce genotypes inoculated with three Pectobacterium carotovorum subsp. carotovorum isolates with increasing degree of virulence Pcc-36 < Pcc-A1.1 < Pcc23 under greenhouse conditions.

\begin{tabular}{|c|c|c|c|c|c|c|c|}
\hline \multirow{2}{*}{ Genotype } & \multirow{2}{*}{$\begin{array}{l}\text { Previous } \\
\text { Class }^{1}\end{array}$} & \multicolumn{2}{|c|}{$\begin{array}{l}\text { Low virulence } \\
\text { Pcc-36 }\end{array}$} & \multicolumn{2}{|c|}{$\begin{array}{l}\text { Moderate virulence } \\
\text { Pcc-A1.1 }\end{array}$} & \multicolumn{2}{|c|}{$\begin{array}{l}\text { High virulence } \\
\text { Pcc-23 }\end{array}$} \\
\hline & & $\mathrm{Sev}^{2}$ & Class $^{3}$ & $\mathrm{Sev}^{2}$ & Class $^{3}$ & $\mathrm{Sev}^{2}$ & Class $^{3}$ \\
\hline Veneza Red & $S$ & $2.3 \mathrm{aB}$ & MR & $2.5 \mathrm{bB}$ & $S$ & $3.5 \mathrm{bA}$ & $S$ \\
\hline Red Hortec & $S$ & $2.4 \mathrm{aB}$ & MR & $2.7 \mathrm{bB}$ & $S$ & $3.2 \mathrm{cA}$ & $S$ \\
\hline Lettuce Red (1) & S & $2.3 \mathrm{aB}$ & MR & $3.0 \mathrm{aA}$ & $S$ & $3.2 \mathrm{cA}$ & $S$ \\
\hline Lucy Brown & $S$ & $2.2 \mathrm{aC}$ & MR & $2.9 \mathrm{aB}$ & $S$ & $4.0 \mathrm{aA}$ & $\mathrm{HS}$ \\
\hline Greek Lettuce & MR & $2.0 \mathrm{aB}$ & MR & $2.5 \mathrm{bA}$ & $S$ & $2.8 \mathrm{cA}$ & $S$ \\
\hline Mimosa Salad Bowl Red & MR & $2.3 \mathrm{aA}$ & MR & $2.5 \mathrm{bA}$ & $S$ & $2.7 \mathrm{cA}$ & $S$ \\
\hline Lívia & MR & $2.0 \mathrm{aB}$ & MR & $2.4 \mathrm{bAB}$ & MR & $2.7 \mathrm{cA}$ & S \\
\hline Livínia & MR & $2.2 \mathrm{aB}$ & MR & $2.4 \mathrm{bAB}$ & MR & $2.7 \mathrm{cA}$ & $S$ \\
\hline Salad Bowl & MR & $2.1 \mathrm{aB}$ & MR & $2.3 \mathrm{bAB}$ & MR & $2.6 \mathrm{cA}$ & $S$ \\
\hline Vitória de Santo Antão & MR & $2.0 \mathrm{aA}$ & MR & $2.1 \mathrm{bA}$ & MR & $2.3 \mathrm{dA}$ & MR \\
\hline Saia Veia & MR & $2.0 \mathrm{aB}$ & MR & $2.4 \mathrm{bB}$ & MR & $3.0 \mathrm{cA}$ & $\mathrm{S}$ \\
\hline
\end{tabular}

${ }^{1}$ Resistance class attributed to the genotypes in the first experiment; susceptible (S) and moderately resistant (MR). ${ }^{2}$ Mean severity scores using an ordinal system; mean of ten replicates (one pot with four plants); averages followed by the same lowercase letters in each column and by the same capital letters in each row are not different (LSD test, $p<0.05)$. ${ }^{3}$ The new resistance class determined for the respective isolate: susceptible (S), moderately resistant (MR) and highly susceptible (HS). 
the five lettuce types (crisphead, green leaf, loose-leaf, mimosa, and romaine). However the loose-leaf type presented the lowest mean scores of severity showing the effect of lettuce type in resistance to soft rot. Previous studies have reported differences in resistance among lettuce types when tested against bacterial and fungal diseases. Cultivars of green leaf and batavia lettuces were found more resistant than other types to bacterial spot disease (Bull et al., 2007), and green leaf and looseleaf lettuces were determined as resistant and susceptible, respectively, to black root rot (Sala et al., 2008). In Brazil, green leaf lettuce, which had several genotypes classified as S to soft rot in our study, represent $70 \%$ of the market share.

None of the tested lettuce genotypes in the present study developed an immune reaction. Similarly, Henz et al. (2005) attempted to identify arracacha genotypes resistant to soft rot caused by $P$. chrysanthemi (Dickeya chrysanthemi) and found that the genotypes varied only in their degree of susceptibility and none exhibited an immune reaction. Accordingly, Pérombelon and Salmond (1995) reported that all potato cultivars tested did not show resistance or immunity to Pectobacterium spp. The expression of soft rot resistance in wild potato species was influenced by environmental factors, such as temperature and annual precipitation, and may also be related to the phenotypic plasticity of the species.

The variation in the expression of disease resistance is likely the result of complex interactions between the plant, pathogen and environment that influence disease severity (Chung et al., 2011). Among potatoes, the genotypes CS 90-164-13 and E 2121 (Vitale et al., 2004) have been determined as the most resistant, which should correspond to MR in our classification, and therefore as potential sources of soft rot resistance. However, none of the lettuce genotypes tested were classified as $\mathrm{R}$ to soft rot in this study, highlighting the need for continuing studies to identify sources of resistance.

High genetic variability has been observed in $P$. carotovorum subsp. carotovorum populations infecting Chinese cabbage in the state of Pernambuco, Brazil (Alvarado et al., 2011). In that production region, the wide variety of other vegetables grown in lettuce-producing areas and the many weeds that may act as alternative hosts contribute to the maintenance of variability in $P$. carotovorum subsp. carotovorum (Alvarado et al., 2011). Thus, the use of pathogen isolates with varying degree of virulence in selection experiments makes the selection of sources for soft rot more feasible under the natural conditions of disease occurrence. In the present research, an isolate with intermediate degree of virulence (Pcc-C) was initially used, which allowed for the separation of genotypes in $\mathrm{MR}$ and S classes. However, isolates with greater or lesser virulence compared to Pcc-C influenced the genotype reactions, confirming the importance of the virulence of the pathogen in the lettuce resistance to soft rot.

Except for the less virulent isolate (Pcc-36), most of the 11 genotypes moved from MR to the $S$ class when challenged with the more virulent Pcc isolates (Table 2). This lack of stability in the soft rot pathogen isolates may be related to environmental conditions /Chung et al., 2011) and/or pathogen virulence.

Temperature and humidity affect the density and dynamics of $P$. carotovorum subsp. carotovorum population during the pathogenesis (Moh et al., 2012). Although the mean temperature recorded during the conduction of the resistance-stability assay $\left(29.0^{\circ} \mathrm{C}\right)$ was higher than that recorded during the selection $(26.88$ $\left.{ }^{\circ} \mathrm{C}\right)$, the mean relative humidity was lower $(71 \%$ versus $73 \%$ ). These environmental differences between the two experiments were considered too small to affect the expression of the resistance. Hence, the differences in resistance reaction may be attributed mainly to the varying virulence of the isolates. The difference in virulence was more evident when the lettuce seedlings were inoculated with all three isolates. Isolate Pcc-23 was consistently the most virulent across all genotypes (higher mean score), including the HS genotype Lucy Brown.

The resistance classes determined using the classification system did not align perfectly with the statistical analysis; some MR genotypes did not differ from some $\mathrm{S}$ genotypes $(p<0.05)$ (Table 2). However, most of the resistance classes were consistent and the classification system may be useful for breeding programs.

Vitória de Santo Antão was the only genotype classified as MR to soft rot for all tested isolates. It is tolerant to septoriosis and possesses multiple characteristics appreciated by producers, such as high plant vigor, thick leaves and tolerance to heat and to early bolting. This genotype is among the most commonly consumed looseleaf lettuce cultivars in northeastern Brazil because of its desirable culinary characteristics, including smooth, loose and light-green leaves.

The state of Pernambuco is divided into mesoregions called Mata, Agreste and Sertão. The Mata has high rain precipitation, large plantations of sugarcane (Saccharum officinarum L.) and also grows vegetables. The Agreste presents less rain precipitation, cultivating beans (Phaseolus vulgaris L.), corn (Zea mays L.), cassava (Manihot esculenta Crantz) and vegetables. In 2004, the prevalence of the soft rot in 42 sampled areas of the Mata and the Agreste was $42.9 \%$, the incidence ranging from $0 \%$ to $22 \%$. Highest incidences (5.7 and $5.3 \%$ ) were observed in the type Loose curly, cultivars Cacheada and Elba, respectively, while the lowest incidences 10.0 and $0.8 \%$ ) were observed in mimosa and loose-leaf types, respectively, even when cultivated in the same environmental conditions of temperature and humidity (Silva et al., 2007). The low disease incidence found in loose-leaf type lettuce by Silva et al. (2007) and in this work may be correlated to varietal resistance and may perhaps explain why loose-leaf type lettuce is widely grown (38.1 $\%)$ in Mata and Agreste of Pernambuco.

Vitória de Santo Antão is a promising candidate for future breeding programs and an excellent choice for 
areas at higher risk for soft rot epidemics. The identification of resistance in commercial cultivars is advantageous because they already possess many desirable characteristics and few undesirable characteristics like those found in wild-species accessions. Because no immune reaction was found, the disease should be managed using integrating genetic resistance with cultural practices such as roguing, management of crop residues, crop rotation, soil drainage, and use of calcium-rich fertilizers (Agrios, 2005; Czajkowski et al., 2011; Wright et al.; 2005).

\section{Acknowledgements}

We acknowledge the National Council for Scientific and Technological Development (CNPq) for awarding a scholarship to Kátia C. S. Felix and a research fellowship to Rosa L. R. Mariano and Elineide B. Souza. We also thank the Foundation for Science and Technology of the State of Pernambuco (FACEPE) for providing financial support (APQ 0583-5.01/08).

\section{References}

Alvarado, I.C.M.; Michereff, S.J.; Mariano, R.L.R.; Souza, E.B.; Quezado-Duval, A.M.; Resende, L.V.; Cardoso, E.; Mizubuti, E.S.G. 2011. Characterization and variability of soft rot-causing bacteria in Chinese cabbage in northeastern Brazil. Journal of Plant Pathology 93: 173-181.

Agrios, G.N. 2005. Plant Pathology. Elsevier Academic, Burlington, MA, USA.

Bull, C.T.; Goldman, P.H.; Hayes, R.; Madden, L.V.; Koike, S.T.; Ryder, E. 2007. Genetic diversity of lettuce for resistance to bacterial leaf spot caused by Xanthomonas campestris pv. vitians. Plant Health Progress DOI: http://dx.doi.org/10.1094/PHP2007-0917-02-RS

Cariddi, C.; Sanzani, S.M. 2013. A severe outbreak of bacterial lettuce soft rot caused by Pectobacterium carotovorum subsp. carotovorum in Apulia (Italy). Journal of Plant Pathology 95: 441-446.

Charkowski, A.O. 2006. The soft rot Erwinia. p. 423-505. In: Gnanamanickam, S.S., ed. Plant-associated bacteria. Springer, Dordrecht, The Netherlands.

Chung, Y.S.; Holmquist, K.; Spooner, D.M.; Jansky, S.H. 2011. A test of taxonomic and biogeographic predictivity: resistance to soft rot in wild relatives of cultivated potato. Phytopathology 101: 205-212

Czajkowski, R.; Pérombelon, M.C.M.; van Veen, J.A.; van der Wolf, J.M. 2011. Control of blackleg and tuber soft rot of potato caused by Pectobacterium and Dickeya species: a review. Plant Pathology 60: 999-1013.

Hyman, L.J.; Toth, I.K.; Pérombelon, M.C.M. 2002. Isolation and identification. p. 66-77. In: Pérombelon, M.C.M.; van der Wolf, J.M., eds. Methods for the detection and quantification of Erwinia carotovora subsp. atroseptica (Pectobacterium carotovorum subsp. atrosepticum) on potatoes: a laboratory manual. 2ed. Scottish Crop Research Institute, Invergowrie, UK.
Henz, G.P.; Reifschneider, F.J.B.; Santos, F.F. 2005. Reaction of arracacha genotypes to the root soft rot caused by Pectobacterium chrysanthemi. Pesquisa Agropecuária Brasileira 40: 95-98.

Jung, Y.J.; Choi, C.S.; Park, J.H.; Kang, H.W.; Choi, J.E.; Nou, Ill-Sup; Lee, Y.S. 2008. Overexpression of the pineapple fruit bromelain gene (BAA) in transgenic Chinese cabbage (Brassica rapa) results in enhanced resistance to bacterial soft rot. Eletronic Journal of Biotechnology. DOI: http://dx.doi. org/10.2225/vol10-issue4-fulltext-5

Koh, Y.J.; Park, J.I.; Ahmed, N.U.; Jung, H.J.; Kang, K.K.; Hur, Y.; Lim, Y.P.; Nou, Ill-Sup. 2013. Enhancement of resistance to soft rot (Pectobacterium carotovorum subsp. carotovorum) in transgenic Brassica rapa. European Journal of Plant Pathology 136: 317-322.

Moh, A.A.; Massart, S.; Jijakli, M.H.; Lepoivre, P. 2012. Models to predict the combined effects of temperature and relative humidity on Pectobacterium atrosepticum and Pectobacterium carotovorum subsp. carotovorum population density and soft rot disease development at the surface of wounded potato tubers. Journal of Plant Pathology 94: 181-191.

Pérombelon, M.C.M.; Salmond, G.P.C. 1995. Bacterial soft rots. p. 1-20. In: Singh, U.S.; Singh, R.P.; Koshmoto, K., eds. Pathogenesis and host specificity in plant diseases: histopathological, biochemical, genetic and molecular bases. Pergamon, Oxford, UK.

Ren, J.; Petzoldt, R.; Dickson, M.H. 2001a. Genetics and population improvement resistance to bacterial soft rot Chinese cabbage. Euphytica 117: 197-207.

Ren, J.; Petzoldt, R.; Dickson, M.H. 2001b. Screening and identification of resistance to bacterial soft rot in Brassica rapa. Euphytica 118: 271-280.

Sala, F.C.; Costa, C.P.; Teixeira, L.D.; Fabri, E.G.; Blat, S.F. 2008. Lettuce reaction to black root rot caused by Thielaviospsis basicola. Horticultura Brasileira 26: 398-400 (in Portuguese, with abstract in English).

Sala, F.C.; Costa, C.P. 2012. Retrospective and trends of Brazilian lettuce crop. Horticultura Brasileira 30: 187-194 (in Portuguese, with abstract in English).

Silva, A.M.F.; Mariano, R.L.R.; Michereff, S.J.; Silveira, E.B.; Medeiros, F.H.V. 2007. Survey of the intensity of soft rot on lettuce and Chinese cabbage in Pernambuco. Caatinga 20: 8493 (in Portuguese, with abstract in English).

Snijder, R.C.; Tuyl, J.M. van. 2002. Evaluation of tests to determine resistance of Zantedeschia spp. (Araceae) to soft rot caused by Erwinia carotovora subsp. carotovora. European Journal of Plant Pathology 108: 565-571.

Vitale, S.; Alberino, S.; Zoina, A.; Parisi, B.; Corazza, L. 2004. Evaluation of resistance to dry and soft rot of potato clones adapted to Mediterranean regions. Phytopathology Polish 34: 13-20.

Wright, P.J.; Triggs, C.M.; Burge, G.K. 2005. Control of bacterial soft rot of calla (Zantedeschia spp) by pathogen exclusion, elimination and removal. New Zealand Journal of Crop and Horticultural Science 33:117-123.

Zhang, J.X.; Lin, B.R.; Shen, H.F.; Pu, X.M. 2012. First report of bacterial soft rot of potato caused by Pectobacterium carotovorum subsp. carotovorum in Guangdong, Province of China. Plant Disease 96: 1109. 